\title{
Heterogeneity of the Notion of Interest in Accordance with the International Relations Theory: A Study of Russia's National Interests
}

\author{
Jarosław Sadłocha \\ University of Wroclaw \\ Institute of International Studies \\ e-mail: jsadlocha@wp.pl
}

\section{Abstract}

The category of a national interest is one of the most popular notions used in international relations. It has a polysemic character and is differently interpreted by various scientific perspectives. The purpose of this article is to provide a brief analysis of selected approaches of the theory of international relations to defining interests and correlating the interpretations of national interests of the Russian Federation performed on their bases. The choice of case study concerning the foreign policy of the Russian Federation is not accidental because in countries aspiring to gain world power the concept of national interest is raised while explaining the motives of decisions taken by their leaders exceptionally often. In this article, Russia's interests will be discussed in reference to the annexation of the Crimea and Russia's actions towards Ukraine. Those events vividly show the specificity of defining the national interests, based on one hand on the pursue to being a powerhouse and understanding the interests in the category of power and, on the other hand, resulting from the political identity of Russian elites. As a result, an assessment of the scientific utility of selected theoretical paradigms and their use in the analyses of Russia's foreign policy will be outlined.

Keywords: national interest, theory of international relations, Russia's foreign policy, the annexation of the Crimea. 
The category of interest plays a role of an analytical tool in the international relations theory, representing potential or real objectives and purposes of the actors of the international relations arena ${ }^{1}$. It has a polysemic character and is differently defined, explained and interpreted by various research perspectives. In literature devoted to the science of international relations, the category of interest appears while analysing various social phenomena related to the problem of articulation of one's objectives, needs and values by the international relations actors. The researchers, however, often define the notion of 'interest' cursorily, frequently treating it as obvious and assuming it does not require further conceptualization.

The purpose of this article is to conduct a brief synthesis of selected approaches of the international relations theory to defining the 'interest', and to correlate the resulting interpretations of the interests of the Russian Federation. The choice of the case study concerning the foreign policy of the Russian Federation is not accidental. In countries aiming at the great power status, the concept of national interest is raised while explaining the motives of decisions taken by their leaders exceptionally often. In the recent few years, Russia has made a number of aggressive moves (starting with the war in Georgia, the annexation of the Crimea, the war in Donbass and the military intervention in Syria) explaining the turn of its foreign policy by a reference to the protection of its basic national interests. Examining the historical analogy concerning the basic objectives of the foreign policy of the House of Romanov and later the USSR, one might ask whether Russia has its enduring and long-ago defined national interests or whether they change along with the identity of the Russian country? Do the national interests in the context mentioned above constitute objective norms determining the actions of the country in international relations? Do they carry values related to the identity of the country and its citizens, or do they merely constitute political metaphors used by the policymakers in the current political discourse?

Correlating two such wide problems as the theoretical analysis of the category of interest in international relations and the question of Russia's foreign policy requires condensing and selecting theoretical problems and defining the range of the case study. Therefore, this article will be limited to indicating the utility of given theoretical approaches, narrowing the questions of defining its national interests by Russia to the context of its actions towards Ukraine, the annexation of the Crimea and the international reactions to these events which clearly show the changes in defining Russia's national interests and its conflict of interests with western countries.

The article will start with a realist comprehension of the national interests of the Russian Federation in the context of the annexation of the Crimea, which then

1 This article has been written within a research program financed by National Science Centre granted based on the decision number DEC-2011/03/N/HS5/00986. 
will be confronted with the perspective of the liberal interpretation of the approach of the West towards Russia's actions. This will, on one hand, show the traditional way of perceiving international relations and, at the same time, show the positivist understanding of the category of national interests. The second part of the article will start with a constructivist ponderation on the importance of national interests, as exemplified by the influence of identity and ideation factors on Russia's foreign policy. Then, based on conventional and critical constructivism, the conflict of interests of Russia and Ukraine at the time of social protests in Ukraine in 2013 and the problem of defining Russia's interests in relation to the annexation of the Crimea will be analysed.

\section{The realist category of the interest in the foreign policy of the Russian Federation}

Realism, one of the most influential currents in the international relations theory, next to the category of sovereignty and country's power places the notion of the national interest in the centre of its ponderations. Despite the enormous diversity of this paradigm, each of its variations considers the fact of having and realizing their own interests by given countries as an almost constitutive rule. Moreover, most of the theoretical assumptions of realism is constructed in a way which enables objective and rational research on the clashing interests of countries in international relations.

Hans J. Morgenthau, a leading representative of realism, in his work Politics Among Nations initiated thinking about interests as objective and definable states which subdue to rational assessment and verification by scientific tools of political realism (Morgenthau, 4-15). According to Morgenthau, a national interest is a category which is closely related to the notion of power: what we define as power is operationalized in practical political actions considered as national interests.

Therefore, in the concept mentioned above it is not possible to speak of interests without exploring the category of power. In the view of Hans Morgenthau, the notion of power has a relational character and is defined as control of a man over a man, embracing any social relations. Transferring it from the level of an individual to international relations, the power of a country can be measured only by comparing it to the power of another country. Determining national interests will in this context serve gaining this power and advantage over other subjects. Power may therefore serve the function of an independent variable and countries' interests will depend on their character and specificity. What is more, in this context power is treated as a sum of certain resources that can be measured and named ${ }^{2}$.

2 One must remember, though, that numerous opponents of this approach emphasize that the above interpretation simplifies realism to one of the forms of materialism, and the international 
Based on the assumptions mentioned above, realists could describe the Russian Federation as a perfect example of a country whose interest could be understood as pursuit of power. Yevgeni Primakov already in 1996 claimed that Russia was still a great power and its foreign policy should reflect this status. The Russian politician expressed himself in the spirits of the best tradition of Realpolitik: "Russia doesn't have permanent enemies, but it does have permanent interests" (Primakov).

Vladimir Putin is driven by a similar way of thinking in constructing Russia's foreign policy. He realizes the consciously set objectives and, so far, has not suffered great losses apart from the consequences related to economic sanctions imposed by the West (Kelly, de Carbonnel). Among Russia's success there are: taking complete control over Chechnya, gaining dominion over the South Ossetia and Abkhazia after victorious war with Georgia in 2008, diplomatic victory over the United States in relation to the plans of solving the political situation in Syria, the annexation of the Crimea and freezing the conflicts in the Eastern Ukraine. In the light of realism, all those actions are very specific and objective purposes which are to bring back Russia's political and territorial influence from the times of the USSR. In this sense, they reflect timeless interests abidingly ascribed to the Russian Federation.

Combining a political and economic blackmail (e.g. gas blackmail) with a direct use of military force, Russia is building its position in the international relations, showing the international public opinion how little power any normative restrictions and the activity of organizations and institutions protecting those standards do in fact have. The foreign policy doctrine used by Vladimir Putin reflects the thesis propagated by another representative of realism, Edward Carr, who claimed that the international order is essentially based on the distribution of strength and power (Carr, 76-80). Just like western countries are trying to implement certain rules and norms regulating the international relations in accordance with their own rules and values, so does Russia selectively choose the ones which serve its best interests at a given time, thus justifying the legitimacy of the actions taken (e.g., protection of the Russian population or the alleged breaking human rights by actions in Ossetia, Georgia etc.) and ignoring others which could turn out to be limiting in this specific situation.

According to realists, any international guarantees are valid only when they are reflected in the distribution of the countries' power. If the countries in charge of those rules are not interested in holding the subjects who break them responsible, the treaties themselves do not have any validity, just like in the case of the Budapest Memorandum from 1994 in which the United States, Great Britain and Russia guaranteed the territorial integrity of Ukraine in exchange for Ukraine's removing nuclear weapon from its territory.

relations to a fight for natural resources. More: Michael Williams, The Realist Tradition and Limits of International Relations. Cambridge: Cambridge University Press, 2005, p. 109. 
Neorealists, though, would present a slightly different view on the way Russia views its national interests. One of the basic differences between classical realism and neorealism is the level of the analysis of international relations (Singer). Transferring the attention from the level of countries to the level of the international structure conditions the perception the perception of the notion of interests. Kenneth Waltz, the creator and the most significant representative of structural realism, claims that the actions of given countries depend on their role, position and political system. The fact whether a country neighbours with powerhouses, middle or weak countries will condition its targets, and, as consequence, its actions (Waltz, 78-81). The international structure determines whether a country's purpose is fighting for its position, maintaining the status quo or minimizing negative effects of the policy of more powerful countries. Maximizing one's interests by a given country will never be achieved in 100\% because they may be incompatible with the interests of other subjects in the structure and, as a result, may be changed. Therefore, countries' policymakers should always account the features of the international structures to which they belong and take into consideration a real potential of one's country, its power of thrusting its interests and corelate them with the interests of other subjects in the structure.

Contrary to the classical realism which considers the pursue to maximize one's power to be the fundamental objective realized by countries of national interests, neorealism believes that the realization of this objective is of secondary importance next to ensuring existence and continuance of the country (Burchill, 42-49). Comparing this approach to Morgenthau's views, it may be concluded that survival is an objective interest. Other types of interests are a bit more relative to neorealists and dependant on external factors such as the structure of the international system and the actions of other countries (Donnelly, 31).

Russia's policy is based on rational calculation of interests and actions of other subjects of international relations, which is in accordance with neorealists. If Russia notices political weakness of the European Union and the United States of America, which was proven e.g. by a complete failure of the American policy in Syria, it strives to use the situations coming its way to realize its own objectives. Even the most controversial decisions concerning the war with Georgia or the annexation of the Crimea could be interpreted from a realist point of view as a rational calculation of possible gains and losses. If further calculations of Russian authorities concerning further annexations (from the western point of view) or protecting the already existing (from Russia's point of view) area of influence or even annexation of further territories, such as Eastern Ukraine or Moldovia brought about similar conclusions, following the logic described above further revisions would not be out of the question. Therefore, appropriate reactions of other countries to Russia's actions may play an important role in limiting Russia's feeling of impunity resulting from its actions. In accordance with the realist logic, western countries 
support Ukraine for similar reasons to Russia - they also aim at extending their areas of influence. In the early 1990s Russia similarly interpreted NATO's willingness to include countries from East-Central Europe, which was one of the reasons why they opposed the possibility of placing American military bases in Poland and Romania.

After the annexation of the Crimea, in his speech to the duma Vladimir Putin said that Russia was not causing any disturbance in the international order, but merely protecting its national interests. It was the West that was causing disturbance through its actions against Russia, Ukraine and European-Asian integration (Putin, 18.03.2014). By saying so, the Russian president adumbrated the area of influence of his country, indicating time that protection of the country is of a defensive and existential character for the functioning of Russia in international relations. Sergey Karaganov held similar views; he considered Russia's victory in the war with Georgia in 2008 to be a demonstration of power to protect one's fundamental interests against Russia's rivals, i.e. preventing the extension of NATO (Karaganov).

However, according to neorealists, countries cannot afford to freely maximize their power due to structural limitations resulting from interests of other subjects. Therefore, in Russia's interest it is to skilfully balance on the border of possibilities of realizing their strategic plans and probing how much they afford without taking potential political or economic consequences and it is doing quite well in this matter. The example of Russia may also indicate that some countries may afford much more than others when it comes to breaking the international law. The regimes of Saddam Husain or Mu'ammar al-Kaddafi were punished relatively quickly, however, they were much weaker in their political range and military force than Russia and they constituted a very important area for western countries from the point of view of oil resources. Thanks to the authoritarian system of power built by Putin (enhancing taking national decisions), appropriate economic situation in the primary products markets (enabling economic power), military force and economic dependencies, any fight with Russia, even only in the economic field, would be related to great costs for its potential opponents. The structural position raised by Kenneth Waltz, possessed by Russia, allows the country to realize the political objectives it has set within the area of its influence without any fear.

The problem of motivation of a country's policymakers or the subjective perception of a country's power is presented by the representatives of neoclassical realism, i.e. William C. Wohlforth and Randall Schweller. Although this view was no revelation since it was proclaimed by some constructivists, postmodernists and researchers of political psychology, in the light of the realist thought it caused a stronger emphasis on the role of non-materialistic factors in shaping international relations (such as e.g. awareness). Wohlforth used this concept to explain the actions of the United States and the USSR at the time of the Cold War. In his 
opinion, the perception of power of those two powerhouses then was often inadequate in relation to their real potentials (Wohlforth, 301-302). The way politicians understand power, both in relation to their own country and other subjects, is not a simple transfer of statistical data from a given period but result from the influence of historical and social convictions, which definitely brings neoclassical realism and constructivism closer.

In Deadly Imbalances: Tripolarity and Hitler's Strategy of World Conquest Randall Schweller proposes a concept of combination of interests with relative potentials of the countries, which he calls a theory of balance of interests, to be a method of explaining actions of countries in the international relations. According to the author, this concept is to explain types of actions taken by countries depending on their relative potentials of acting on the international arena. Those actions are influenced by a relative strength of the country (military strength, industrial strength and demographic potential), motivation of policymakers, relations with other subjects and their attitudes towards international order (Schweller, 190-191).

On the bases of the theory of balance of interests by Randall Schweller one may come to a conclusion that Russia, thanks to its relative power, appropriate motivation of its main policymaker and ambivalent attitude towards the international law, may be treated as a country with all the attributes allowing for a limited revisionist foreign policy (Schweller, 18-24).In case of Russia, of great significance was appropriate economic situation, prices of fuels (ensuring a better economic situation), determination and political ambitions of Vladimir Putin. The president of Russia often emphasizes in his statements that the fall of the USSR was one of the greatest geo-political catastrophes of the $20^{\text {th }}$ century (Putin, 25.04.2005). It is also worth to notice that in accordance with the theory of balance of interests, the casus of Russia may in further perspective become a dangerous precedence constituting an example the strategic plans of other subjects of a similar position, such as e.g. China in relation to its territorial expansions on the South China Sea.

In turn, according to the theory of Robert Gilpin, pursuit of complete gain is not what constitutes an exclusive interest of each country; it is also maximizing available strategies of actions (Gilpin, 61). Thanks to the quick pace of taking decisions and using diversified political strategies, starting with conciliation methods to immediate use of force, Russia may be considered a country that is exceptionally ready to react in any situation of a change of a system. It may cause a far-reaching caution of its geopolitical rivals, particularly if they are not ready themselves to react immediately and adequately to the specificity of a given international situation. On the other hand, neorealism would also emphasize that Russia must remember that if it does cross a certain border of tolerance in its foreign policy, its actions will sooner or later be counteracted. Much less that its real potential departs from the power represented by the USSR in the utmost period of the Cold War. 
Apart from emphasizing the role of non-materialistic factors in formulating national interests, representatives of the neoclassical realism also suggest that while defining their interests, the countries do not separate their egoistic actions based on rivalry (e.g. in order to ensure safety or basic strategic interests) from actions based on cooperation with other subjects which also bring them some gains of political or economic nature (Lobell, Ripsman, Taliaferro, 30). This logic well describes the way of functioning of Russian foreign policy towards the West, which Russian researchers describe as simultaneous partnership and rivalry Tsygankov 2010, 43-51; Bordachev 2008) As Elena Kropatcheva points out, most Russian analysts perceive international relations very pragmatically and are much closer to the realist option of perceiving the notion of national interest (Kropatcheva, 33-34). Referring to the question of cooperation, they present a view that Russia consciously and rationally chooses the fields in which the international cooperation is in accordance with materialistically perceived national interest and rejects all those areas in which the cooperation is not beneficial. This can be illustrated by the 18-year-long endeavour to join the WTO. It is also worth to mention Russia's participation in the international area of fighting terrorism and the solidarity with western countries after the $9 / 11$.

According to the logic of Russian realists, its fundamental interest is to strengthen the country's potential with simultaneous eviscerating the power of other countries (Bogaturov). This, in turn, is closely related to Russia's aspirations to being perceived as one of the greatest powerhouses in the world, a belief expressed not only by the most important politicians, but also by majority of the society (Areshev, 128-142). The problem of the role of identity in the way the Russians perceive their interests and the social discourse in this area is shaped will be covered in the further part of this article which is devoted to the constructivist approach.

\section{Liberal understanding of interests and the attitudes of western countries towards Russian policy}

To present the differences in perceiving the category of a national interest between the widely understood realism and liberalism in a possibly brief manner, it is worth to refer to the reaction of western countries to Russia's actions towards the annexation of the Crimea and the war in the Eastern Ukraine. One can find there both references to the interwar idealism and to modern interpretations of understanding interests in international relations by representatives of neoliberalism.

Taking a close look at the reaction of the United States and member countries of the European Union and NATO towards Russia's aggressive policy - be it in the context of the war with Georgia in 208 or the annexation of the Crimea in 2014 - one may conclude that many commentators contrasted the safeguard 
behaviour of the West with the aggressive and uncompromising attitude of Russia, characterised by $19^{\text {th }}$-century-like pragmatism in the style of Realpolitik. Those differences are explained in an interesting manner by almost forgotten nowadays idealism represented by, among others, Norman Angell, the Novel Peace Prize laureate who might interpret Vladimir Putin's attitude as an obsolete state of mind perceiving international relations as an arena of a constant rivalry in a binary game. Angell believed that such an attitude should be condemned from the level of the international community and under no account should be followed because it may only lead to increasing rivalry, arms race and further to wars. From this perspective liberalism emphasizes that Russia's actions are not compliant with the international law and will have negative impact on its image and credibility as a partner in international relations. However, they should be counteracted in a thoughtful manner so that Russia could see that its actions are condemned and not approved of by the international community; on the other hand, though, those reactions should be compliant with the international law, so that they do not contribute to the escalation of conflicts which, as neoliberalism points out, would be unbeneficial for the interest of any party from both the political and economic point of view ${ }^{3}$. Therefore, from the position of neoliberalism one may emphasize the significance of multilateral solutions brought with the use of any means of solving conflicts, i.e. negotiations or - if they are not successful - political or economic sanctions, and as a last resort of military intervention.

The reaction of western countries seems to be compliant with the main idea of neoliberalism. They focused on one hand on condemning Vladimir Putin's policy, imposing visa and economic sanctions and, on the other hand, they are aware of the number of economic relations they have with Russia and breaking them does not lie in their best interest. That is why the greatest economic partners of Russia from the European Union, such as Germany, consider the idea of imposing economic sanctions as a last resort and do not even consider any military intervention. Neoliberalism also shows the difference in the general understanding of the interests by the greatest countries of the European Union and Russia. In accordance with the neo-realist logic, Russia calculates its own gains as relative towards the power and potential actions of other subjects, which causes distrust towards the intentions of others and cooperation with them. In the light of neoliberal thoughts, countries such as Germany, France or Great Britain perceive gains as absolute values and

3 It is worth to mention a range of neoliberal concepts viewing the problem of shaping a country's national interests through the prism of international cooperation, such as institutionalism and the model of a complex interdependence by Robert O. Keohabe and Joseph S. Nye, as well as the concept of the international regime by John G. Ruggie. More: Robert O. Keohane, Joseph S. Nye, Power and Interdependence. New York, 2001; John G. Ruggie, Constructing the World Polity: Essays on International Institutionalization. London, 1998. 
strive to neutralize impending conflicts by any means to maintain the cooperation that generates their gains.

Neoliberalism also emphasizes that economic cooperation is not possible without achieving the state of stability and complacency, therefore, it may be presumed that countries of the European Union will be forced to introduce adequate political solutions such as common energy policy tools (to prevent gas blackmail), institutional help for Ukraine and other European countries potentially facing the threat of Russia's actions and - finally - finding a new form of dialogue with Russia. Although it seems to be necessary from the strategic point of view of consistent functioning of the European Union, it may be very hard to achieve. The differences of interests of given member countries almost paralyse taking any firm decisions. In accordance with the concept of countries' preferences, postulated by intergovernmental liberalism of Andrew Moravcsik, the attitudes of member countries of the European Union may be interpreted as a rational calculation of gains and losses on every level of articulation and aggregation of their interests (Moravscik, 517-519). This calculation depends both on conscious needs of the subjects, their profit and loss accounts and their decision-making conditioning. The countries of the European Union must take into account both the position of the influential internal groups of interest (international corporations, occupational groups, non-governmental organizations etc.) which may be interested in maintaining a stable level of trade with Russia and the voice of the society which, depending on the historical and geographical specificity of a particular country, may consider lack of condemnation of Russia and any other Union's reactions related to it in a negative manner or, just the opposite, be entirely indifferent towards those events and not support any radical actions.

It should be mentioned here that Russian researchers of international relations believe that the West did not use the exceptional opportunity to include Russia in the multilateral international order which it approved of through building close political and economic relations, which appeared in the 1990s. As Alexei Arbatov points out, western countries indeed used the period of Russia's political and economic weakness under the cover of cooperation in order to interfere in its affairs and limit its areas of influence (e.g. extension of NATO and EU). That is why Russia has currently a pragmatic attitude towards lofty ideas hidden under the term 'international cooperation' (Tsygankov, 43-51; Arbatov). What is more, in Russia's policy one may observe ideas borrowed from liberal logic, e.g. creating its own networks of economic dependencies (e.g. creation of the Eurasian Economic Union) which are used by them in an instrumental manner. However, also in this range a fuller outline of the problem may be seen only after referring to the problem of identity and values standing behind the "international communities" built by Russia. 


\section{Constructivist perception of Russia's national interests}

Why in the recent few years have we been witnessing such a rapid political turn of Russia on the international arena? After the fall of the USRR and the political and economic crisis which Russia suffered in the 1990s, does its leader redefine its fundamental strategic objectives again? The realist perspective cannot provide a full answer to this question because it does not deal with the problem of identity and non-materialistic factors in the process of constructing national interests deep enough. It also has problems explaining the impact of reason of the change of motivation which drive the policymakers while determining national interests and the rapid increase of significance of cultural and identity factors in the social discourse.

According to Alexander Wendt, until recently the problem of national interests has been wrongly treated in the theory of international relations as a domain ascribed to solely the interests of realism. The materialistic view on the process of shaping of the interests done with the use of the distribution of potential and power of the subjects and referring to the human nature, as proposed by this paradigm, is not full because it omits social aspects of constructing interests. Wendt believes that countries do not have a universal "portfolio" including a catalogue of all cognitively available interests on the bases of which they take decisions, as it could arise from the neo-realist analyses, but they make their decisions on the bases of individual features of their own identity and the social context of decision making (Wendt $1992,398) \cdot$ Interests, although they take into consideration and refer to material features of the human nature, are largely of a character of ideation, i.e. are constituted by culture and social ideas (Wendt 1999, 113-119).

In accordance with Wendt's conventional constructivism, interests are cognitive patterns which enable identification of objects satisfying one's needs. Those patterns refer to convictions and "structures of knowledge" about the world of a given subject. They serve those subjects to identify themselves (in the form of identity) and interpret their actions and objectives in given situations which require their activity. Defining one's interests is closely related to the subject's identity. According to Wendt, identity is shaped dynamically both by internal factors such as sociallycultural conditioning and by mutual interactions with other countries and historical experiences in this range. Countries may have many identities contributing to their images, which are shaped depending on the type of relations, functions and social statuses held by them (Wendt 1999, 224-234). Such an assumption is to cause a conclusion that countries can identify their own interests variously depending on the context and character of a given issue and factors of the character of ideation play an important part in this process.

According to Andrey Makarychev, Putin's administration, driven by such objectives as restoring Russia's historical territories and protecting 
Russian-speaking population is indeed driven by factors of character of ideation and not merely by calculation policy (Makarychev 2014, 181-199). Andrei Tsygankov is of a similar opinion, as while analysing the contemporary foreign policy of Russia he points how the perception of interests in the foreign policy of Russia has changed, starting with the administration of Boris Yeltsin and its orientation towards integration with western countries to the assertive and pragmatic attitude of president Putin (Tsygankov, 226-231). Tsygankow points at two fundamental national interests of Russia in international relations: balancing hegemonic aspirations of the United States and integrating the whole territory included in the former USSR. As the researcher believes, the first objective requires constructing coalition with other countries of similar interests, while the latter is related to recreating and protecting the former areas of influence belonging to Russia (Tsygankov, 236-243).

Subordinating the post-soviet territories to Russia is also taking place by the concept "Russkij mir". According to the interpretation of administration of Vladimir Putin, it is an equivalent of the community of people who speak Russian, identify with the Orthodox religion and culture and refer to common values and historical heritage. At the same time, it refers to a wider political community having relations with the culture and identity of the former USSR. This concept is reflected in Russia's National Security Strategy to 2020, in which Russia defines the Russian-speaking areas of the former USSR as "Near abroad", considering them their vested interest (Strategiya natsional'noy bezopasnosti Rossiyskoy Federatsii do 2020 goda). The fight for the rights for Russia and Russians on this territory is a derivative of not only rational geo-political calculations, but it largely results from the features of current identity of the Russians, their ambitions and powerhouse ressentiments.

The problem of identity in many constructivist works is closely related to the impact of cultural and normative aspects of the articulation of interests which appear both on the level of analyses of political and social cultures of given countries and their societies, and in reference to the structure of the international system. An example of such an analysis is, among others, Social Construction of International Politics by Ted Hopf. The researcher realizes there a practical dimension of research on the relations of interests, identity and social culture on the example of an analysis of the political discourse of the USSR from 1955 and the Russian Federation from 1999, indicating the similarities and differences between the discourses devoted to Russia's interests in both mentioned time periods (Hopf 1999).

In the context of an analysis of Russian national interests, an exceptionally inspiring research perspective constitutes aspirational constructivism by Anne Clunan. The researcher expands the perspective of constructivism by interdisciplinary research on the identity of countries taking into consideration, among others, the role of historical tradition in a given country, tools of social psychology 
and sociology. She criticizes both realists and other constructivists for exaggerated attachment to presentism, marginalizing the impact of historical aspirations and the significance of domestic policy in the process of constructing national interests (Clunan 2009, 4-8). Similar arguments are presented by Andrei Tsygankov who claims that realism and liberalism are ethnocentric in the sense that they do not understand the cultural and civilizational specificity of Russia and in the field of western type of thinking about e.g. rationalism they strive to interpret the political motivations of Russia (Tsygankov, 14).

Representatives of constructivism, such as Anna Clunan, Beom-Shik Shin, Andrei Tsygankov or Ted Hopf, pondering over the national interests of Russia notice that various groups of Russian elites in various time periods emphasized a slightly different way of thinking about foreign policy of this country ${ }^{4}$. The category of the national interest constitutes a derivative resulting from the discourses functioning in the given period within a society and its elites. Those discourses may compete or complete one another, having different power of political influence which depends on their popularity in the circles of power. In case of Russia, all the researchers mentioned above consistently claim that currently the most common national interest shared by majority of the elites is maintaining the international position and prestige by Russia. After the dissolution of the Soviet Union and the crisis of the 1990s, Russian elites believe that their country should regain its due international position.

The opinions mentioned above are corroborated by cyclical research conducted by Hamilton College on a group of representatives of the Russian elites which in 2016 showed an increase in radicalization of the Russians in the recent few years. Most of the subjects (over 82\%) believed that Moscow's national interest should be realized through actions of expansive character. Importantly, a significant increase (by $32 \%$ ) of the followers of revisionist policy took place directly after the outbreak of the conflict between Russia and Ukraine and the annexation of the Crimea. Another exceptionally interesting result of the research was showing the attitude of the Russian elites to the fact whether the military force of economic potential decides currently about the position of a given country in the international policy. Only in 1993 almost $90 \%$ of the interviewees believed that the economy was of an utmost importance. Currently $52 \%$ of the interviewees believes in the primacy of the military potential, while only $46.5 \%$ of the subjects tested believes that the economic position is the most important (Hamilton College Levitt Poll, The Russian Elite 2016). Similar conclusions can be drawn from Russian polls conducted by Levada's Centre, in which $68 \%$ of the Russians in 2015 considered their country to be

4 More: Beom Shik Shin. Russia's Perspectives on International Politics: A Comparison of Liberalist, Realist and Geopolitical Paradigms, "Acta Slavica laponica", no. (26) (2007), pp. 1-24; Ted Hopf, Crimea is ours: A discursive history, "International Relations", no. 30(2) (2016), pp. 227-255; Anne Clunan, op. cit., s. 76-79; Andrei Tsygankov, op. cit., s. 182-183. 
a powerhouse, while still in 1999 only $31 \%$ of the respondents believed so (Levada Center Poll, Russia's role in the world).

On the bases of this view, the annexation of the Crimea and the war in the Eastern Ukraine suits the expectations of the Russian elites in terms of their interpretation of the interest of their country. The trend described above also indicates that currently majority of the Russian elites perceives international relations in the style of the $19^{\text {th }}$ century, while the society of western countries mostly look at the wold in the postmodern formula with a weakening sovereignty of countries, increasing process of globalization, and the values excluding the hard way of solving conflicts. This in turn causes that differences in the interpretation of the surrounding social world and further may lead to increasing misunderstanding and feeling of alienation. Therefore, when western countries imposed economic sanctions on Russia, most of the society (66\%) was not afraid of international alienation of Russia. They considered this form of an attack for their beliefs and values and, therefore, required a more outright and harsh reaction of the authorities to the restriction from the USA, supporting among others the embargo imposed by Russia on western aliment (78\%) (Levada Center Poll, Sankcii: ocenki i ożydanija).

Ann Clunan indicates that the fall of the Soviet Union was the main cause of the crisis of the national identity and low self-esteem of the Russians. The researcher points out that in the 1990 s in Russia appeared five different self-images competing with one another: western self-image, statist self-image, national restorationist self-image, neo-communist self-image and slavophile self-image. Each one of them referred to slightly different historical traditions and emphasized a different catalogue of values and identity while defining the fundamental interests which Russia should pursue. Thanks to the success and the increasing popularity of Putin's administration, the statist self-image referring to the powerhouse tradition of the Russian country and the necessity of restoring its dominance and leadership in the countries belonging to the former USSR turned out to be victorious (Clunan 2009, 60-66). This approach in Putin's mouth emphasizes among others the civilizational individuality of Russia, faith in its greatness and historical belongings, the role of patriotism, solidarity and social unity of the Russians.

The role of the symbols and the significance of the elements of the language in the examination of the discourse are developed by the linguistic constructivism. Its representative, Jutta Weldes, presents national interests as a function of an intersubjective representation of social views. They embrace social perception of a country's identity, its internal and externa surroundings, including the interests of other subjects and the relations between those factors which altogether constitute parts of the "linguistic image" of the political beliefs concerning priorities of the country's activity (Weldes, 13-15). 
According to Weldes, the social representations constitute a simplified image of collective communication about certain problems or subjects which are attributed some symbolic meaning with the use of certain parts of speech or literary devices. According to the researcher, this type of communication techniques not only function in the dimension of a propaganda, but in time become a natural part of the image of the social world (Weldes, 97-107).

This logic also seems to be very adequate in case of the public discourse of Russia. References to historical tradition, devotions and greatness of the Russian nation throughout the centuries, emphasized by Russian politicians, not only result from their identity, but also constitute an element of the political game they play, aiming at increasing their social popularity. Also, the tools themselves in the form of certain rhetorical figures influence the process of shaping of the collective image of identity of the contemporary Russians. Most often exploited rhetorical phrases acquire in this process certain linguistic connotations and in the long-term perspective become a part of the social understating of reality. This way, e.g. the negative colouring of the word NATO in the rhetoric of the leaders of the USSR still influence the Russian's society perception of this organization as aggressive and expansionist.

Starting from 2013, Vladimir Putin often refers to the role of spiritual and cultural values in the process of shaping the identity and strengthening national unity of the Russians (Slobodchikoff, Douglas, 28-36). Also, in official documents such as "National Security Strategy 2015” one can find direct references to spiritual values, patriotism and respect for tradition which constitute the foundations of the Russian manner of perceiving the world and defining its national interests (Russian National Security Strategy 2015). Russia, understood as one of the highest values for its citizens, has a responsibility of taking care of the interests of the Russian-speaking population in other countries. At the same time, on the bases of this interpretation one can contrast positive interests of Russia resulting from its "spiritual values" with the expansionist interests of the West that is devoid of those values.

An exceptionally spectacular example of a symbolic performance was the inauguration of the $4^{\text {th }}$ tenure of Vladimir Putin's presidency. Built not only by linguistic tools, but also by nonverbal elements, his swearing-in took place in the atmosphere of affluence and wealth alluding to the tradition of the Tzarist Russia. These trappings emphasized not only the political power of Russia's president, but also to show the society the expected power and prestige of the country and its president, the contemporary equivalent of the most remarkable Russian leaders once admired by the world. In his speech the president emphasized that after the political difficulties Russia experienced in the 1990s, it is currently "being reborn like phoenix from ashes" and its due prestige would be restored (Putin, 7.05.2018). 


\section{Constructivism and the social protests in Ukraine and the annexation of the Crimea}

Analysing the problem of the annexation of the Crimea by Russia in 2014, constructivism would pay attention to the role of identity and cultural and normative factors in the process of constructing various interests of Ukraine and Russia. Looking at the specificity of the identity of the society of contemporary Ukraine, one may easily notice a significant division of the citizens into two internally diversified social groups. One of them is the group of Ukrainians originating most often from the western and central part of this country, identifying with their country, their language and culture. The other group are the Ukrainians or the Russians who have Ukrainian citizenship, who are attached to the Russian language and the soviet identity and culture. Those two groups, thought, are separated by the language and culture, but also by completely different political attitudes related to perception of such problems as democracy, freedom or geopolitical leaning. While the first group of the Ukrainians is much more open to the western culture, its values and political system, the other group openly supports political and economic integration with Russia and is sceptic towards widely understood integration of Ukraine with the West, in many cases feeling a great sentiment to the times when Ukraine was part of the USSR (Kapuśniak).

The Orange Revolution from the turn of the year 2004 and 2005 for the first time showed the world how great a role those identity differences between Ukrainians play. Euromaidan at the turn of the year 2013 and 2014 was a kind of repetition of those protests, being directed against the rule of Viktor Yanukovych. The main cause of the protests was social dissatisfaction related to the delay of signing the associational agreement with the European Union by the president. As a result, the rule of the pro-Russian Yanukovych was overthrown, which Russia treated as an unlawful action and a political blow against its geopolitical interests and political values, which was in some part shared by the Russians living in Ukraine and was extremely visible in the Crimea. Realism would explain this situation in the category of a conscious game of interest of the Ukrainian opposition relating the country's objectives with the West and Russia that, at any cost, wanted to keep Ukraine in its area of influence and then, after the overthrow of Yanukowych, destabilize the country by the annexation of the Crimea. However, this approach does not explain where these interests result from and how they are constructed socially (Sadłocha, 173-174).

From the materialist point of view - which professes both realism and neoliberalism - it may seem that it is not beneficial for Ukraine to start a conflict with Russia with which it has numerous economic interests, and which offered a loan amounting to 15 million dollars in exchange for not signing the associational deal 
with the European Union and declared lowering the gas prices, which would be very beneficial for Ukraine in relation to the budgetary difficulties. However, the Ukrainian society protesting in Euromaidan chose opening the country to the West, both in the literal meaning of initiation the European integration as in the sense of introducing western political standards. The social choice of Europe made by the Ukrainians, despite being aware of uncertain and significantly delayed chances for accession to the European Union, may show both normative and cultural strength of the Community's influence and prove the dynamics of shaping the identity and social attitudes related to them which influence defining the interests by a society.

With reference to Russia, the political identity of the Russian elites outlined above - with Vladimir Putin in charge - best defines the reasons of taking the decision of the annexation of the Crimea. Taking the Crimea over from Ukraine, from the materialist point of view may seem an endeavour considered at least risky because it means a range of structural expenses related to adjusting this area to functioning within the Russian Federation (Wierzbowska-Miazga). However, it may remain unassessed from the point of view of shaping the internal identity of the Russian society whose old splendour and prestige of the former USSR is being restored. These arguments were also manifested in the attitude of the Russians living in the Crimea themselves who perceived Russia as a chance for a better life that they experienced during the Soviet times.

Among the aspect emphasized by constructivism there is also the influence of normative structures on the actions of countries in international relations. In case of the aggressive Russian policy towards Georgia or Ukraine it might seem that constructivist theses have rather small analytical translation and Russia did not care much about the opinion of the international community. However, the regime of Vladimir Putin was trying to keep up appearances which would decrease the perception of the Russian identity as an aggressor, initiating - unlawful, but seemingly normatively justified - a referendum on the annexation of the Crimea with the presence of "friendly" international observers, or in the context of the war with Georgia in 2008, proposing the presence of the representatives of the EU and the OSCE (Organization for Security and Cooperation in Europe) in Abkhazia and Ossetia.

The abovementioned initiatives may be criticized for being undertaken only with the purpose of keeping a seeming lawfulness of the already undertaken by Russia unlawful actions and for serving the internal legitimization of those actions. Therefore, constructivist might emphasize that if the international community did not react to breaking the international law, as a result of decreasing the normative credibility of Russia, other countries will change their perception of the country and will influence shaping their relations in the future (Finnemore). On the other hand, Russia skilfully used in its argumentation the casus of the independence of Kosovo in 2008, showing that it is driven by similar normative standards to western countries which ignored the opposition of Serbia in case of Kosovo (Jusufaj). 
Critical constructivism and linguistic constructivism emphasize the roles of symbols and metaphors which are used by the country's policymakers in their political rhetoric, creating certain truths about the world commonly accepted by the society, which are to reflect their own point of view. Therefore, their spreading constitutes an important interest for the politicians seeing internal and international acceptance of the undertaken actions. The fight for the truth, as proclaimed by postmodernists, serves the role of not only propaganda, instrumentally used for the needs of explaining one's actions, but indeed creates an individualistic system of power and dominance, manipulating the social perception of the world and indirectly the process of shaping the identity of the society's interests. In the context of the discussed policy of Russia towards Ukraine, one may notice two antagonistic discourses of truth which treat these problems differently: a western perspective, expressed by the Ukrainian authorities, the countries of the European Union and the United States, compliant with the values and liberal norms resulting from them normative and moral condemnation of the aggressive actions of Russia and the unlawfulness of the annexation of the Crimea; and Russia's position explaining the legitimacy and lawfulness of its policy.

The clash of the points mentioned abode may resemble the ideological conflict of the Cold War in which both parties incompatibly interpreted the political events in the whole world. Rhetorical techniques of Vladimir Putin and his co-workers refer to the language of the leaders of the USSR, particularly when calling the Ukrainian opposition 'fascists', and the protests $n$ Euromaidan and the overthrow of president Yanukovych 'acts of violence and chaos' which were to be 'steered top-down' with the use of e.g. Poland and were not to have a wider acceptance among the Ukrainian society. In the opposition to this, Russia was only aiming to protect the Russian-speaking population in the Eastern regions of Ukraine and the Crimea from the danger. In his solemn speech, Putin argued that the referendum in the Crimea and its annexation were legal and compliant with the international norms and supported by historical respect they were to result from, claiming that the Crimea had always been a part of Russia and was abidingly inscribed in Russia's national identity (Putin, 7.05.2018). The manipulations described above were expressed in the atmosphere of common euphoria of the residents of the Crimea.

Vladimir Putin since 2013 had been talking about a common historical root of those two countries in shape of Kiev Ruthenia and the cultural proximity of those two nations. The president's statements may have suggested that Ukraine and Belarus constitute one of the most important elements being a part of the "Russian world" and it is Russia's duty to maintain close relations with it (Putin, 28.07.2015).

A similar narration concerned the annexation of the Crimea. In 2014, in his proclamation to Russia's Federal Assembly, Putin said “for Russia, the Crimea has 
an enormous civilizational and sacred significance, just like the Temple Mount in Jerusalem for the believers of Islam Judaism" (Putin, 28.07.2015). This statement refers to the fact that in 988 prince Vladimir the Great was baptised in Chersonesos. Calling the Crimea civilizational root of Russia may be considered an audacious rhetorical manipulation serving the purpose of explaining the undisputed relations of the Crimea and history of Russia. His annexation of the Crimea was to be understood as restoring a natural state because handing the Crimea over to Ukraine by Nikita Khrushchev in 1954 was unlawful in Putin's opinion. However, Putin also referred to other symbolic elements connecting the Crimea and the history of Russia, i.e. the Crimean war, graves of the Russian soldiers or the Black Sea Fleet (Putin, 28.07.2015).

It is worth to mention here another historical example referring to the Crimea and the "identity" policy of the USSR. In 1944, by virtue of the decision of Stalin, all the Crimean Tatars inhabiting the peninsula incessantly since the $13^{\text {th }}$ century displaced. Along with the deportation, most of the traces of the culture of the Tatars was destroyed. Material culture, architecture, cemeteries, even natural elements of the landscape such as cypress, the tree characteristic for the Crimea, were all being destroyed (Chazbijewicz). The actions of the USR were then aiming at redefining the identity of the whole peninsula. That suggests the role of the identity in the political process of controlling the society was understood as early as then.

In the opposition to the Russian rhetoric, the discourse in western countries emphasized the territorial integrity of Ukraine. In his speeches, Barrack Obama emphasized the invalidity of the referendum in the Crimea which was only an excuse to its annexation by Russia, condemned Russia's intervention on the territory of Ukraine as not compliant with the international law, threatening with consequences in form of sanctions which would be increasing along with the escalation of Russia's actions (Gostkiewicz). While the position of western leaders referred to the idea of international law and, in their opinion, commonly accepted rules that should be followed in international relations, the Russian discourse deconstructs the existence of such truths, mocking them and demonstrating the validity of the old rule according to which it is the winners who write history. As reported by New York Times, Angela Merkel was to say after a conversation with Vladimir Putin concerning the situation in the Crimea that she "was not sure whether he had not lost his touch with reality" and that he "was in a different world" (Baker). Although the Germans quickly denied this information, they illustrate the shock of clashing with the western point of view on the contemporary international relations with the position of Russia, seemingly irrational and contrary to the liberal vision of truth. In this situation realists would indicate that Putin is not detached from the reality, but that he shows the world how illusory the reality in which the West believes is. Publicists and researchers sympathising with this diagnosis call the perception of the countries of the European Union 'postmodernist philosophy' which 
is to express, among others, pacifism, overly attachment to the problems of cultural liberalization, the cult of human rights and belief in the universality of the order built after the fall of the Cold War and its liberal rules, contrasting it with the harsh reality of the Russian realism in which what prevails is power (Wielomski).

Interestingly, from the perspective of the logic of postmodernism it is Vladimir Putin who might appear to be a master of creating freely chosen truths and their casual serving to the world. Taking into consideration Russia's position, the addressees of those messages must consider them seriously, which constitutes the existence of those manipulation in the international public opinion. The president of Russia consciously uses even the most absurd theses to show its power not only over the situation in the Crimea, but also its normative assessment. This logic is illustrated by words from the novel by Fyodor Dostoevsky Notes from Underground: "two plus two are five". In this novel, Dostoevsky contrasts an ideally functioning society based on the rules of reason with an irrational contestation of this harmony by individuals who reject this order only to show the strength of their own will. According the Alexander Shea, Putin's rhetoric takes form of postmodernist authoritarianism whose aim is to undermine the equity of western thinking and its moral monopoly for setting the truths of humanitarianism, human rights and standards of other countries' actions (Shea). Postmodernists would emphasize that even if Russia's president does realize that his arguments do not convince western leaders, the sole consciousness of the fact that he can manipulate the facts which will be repeated in the whole world indicates the range of the power of his discourse which goes beyond the material potential of the annexation of the Crimea.

\section{Conclusions}

The notion of an interest and it interpretation constitute a linguistic instrument of constructing a certain image of international relations by given paradigms. It is not possible to indicate which approach to understanding the national interest has the greatest analytical value. A realist perspective finds itself well in the context of looking for objective national interests in the anarchistic environment, but it cannot fully explain the social and cultural aspects of shaping of the national interests. With the use of realism, it is easy to explain the motivations of countries that, in their actions or strategies of foreign policy, concentrate on the cult of strength and egoistic pursuit of increasing one's power and security. Such subjects may perceive international relations to be an arena of a constant rivalry oriented at increasing one's political and economic gains achieved at the cost of other subjects, e.g. as a result of a fight with other countries, but also participation in various institutions and forms of international cooperation used by them for their instrumental aims of foreign policy. 
As some observers of international relations suggest, the case of the discussed policy done by the regime of Putin should create awareness of the significance of traditional theories explaining specific problems of international relations. According to Robert Murray, current policy of Russia indicates that we "are not living in the post-sovereign world where countries do not attack other countries, and the complex of co-dependencies and economic relations do not prevent them from strategic thinking resembling the times of the Cold War" (Murray).

According to John Vasquez, realism can explain almost every event within countries' foreign policies but does it "post factum" (Vasquez). Not knowing the results of countries' actions, it is hard to make solid judgements on their compliance with objectively understood national interests. It may also refer to neoliberalism that, better than neorealism, explains those interests in the context of the existence of international cooperation, but just like neorealism it is subjected to harsh criticism from post-positivist approaches for its objectivity, rationality and materialism. Moreover, the positivist theories largely reflect the manner of thinking about the world of western researchers that not always is identified with the logic expressed by other civilizational circles (Sadłocha, 203-204).

The post-positivist theories construct an objective, rational and materialist dimension of presenting the interests in international relations. This view is well expressed by Robert Cox, a leading representative of the critical theory: "a theory always serves someone or something" (Cox). All theories of international relations are shaped in a given time space and political and axiological contexts which determine the knowledge of the world and the analytical assumptions expressed by researchers. In this light, neutrally expressed idea of national interests is only a reflection of subjective knowledge and values of a given subject, all of which may have a specific intentional load. According to Cox, both realism and neoliberalism as so deeply rooted in the international order and the manner of thinking of the developed western countries that they consciously or unconsciously sanction and justify the status quo and support the interests of the political elites which take profits from it. We should ponder on the fact whether this logic may be adequately used also e.g. in particular analyses of the discourse devoted to national interests conducted by researchers related to the post-positivist approaches. The trends indicated by them, related to defining national interests, also are not detached from the worldview and identity of the researcher. That is why we cannot exclude that to some extent they may contest some political order and serve hardening another order through emphasizing particular elements of the political discourse and marginalizing others (Sadłocha, 203-204).

The post-positivist theories only to some extent consider how interests are constructed and what their relation to values and identity of the subjects that formulate them is. The discussed case of Russia has shown that understanding the non-materialist factors, the role of culture and identity may lead to a complete 
misunderstanding of the motivations of a country's actions in international relations, its motivation of the process of defining of national interests. As suggests constructivism, with the use of the mechanisms of examining social discourses, analysing rhetorical figures of the most important politicians, references to polls and the use of deconstruction we may understand the way the national interests are articulated better.

The tradition of Russia's building a strong and expansionist country goes back to the times of Peter the Great and despite the passage of time and the political changes it still creates Russian national identity, perception of the national interests and defining of the objectives of the foreign policy. Perhaps the elements of the Realpolitik policy have become a constant element of the identity of Russian leaders, and social expectations towards the greatness of the Russian country and its prestige in the wold have shaped the current identity of the Russian society. This would mean that in case of Russia one cannot with an absolute power counteract the materialist understanding of national interests, so close to the classical realists, with the constructivist approach. The proximity of materialism and ideation factors have been covered by R.B. Hall, among others (Hall). In order to understand Russia's policy well, it is imperative to take a look at it from those two perspectives.

The pursuit of conscious discussion of the wide spectrum of international relations, embracing various scientific points of view, one must remember about the relativity of the category of interest. Interests are situated in the social world and always refer to relation of one subject with another, both in the area of internal policy and in the international relations. It must be emphasized that those relations may be interpreted from various points of view. Particular paradigms, due to the variety of their ontological assumptions and the specificity of the interest of researchers, have a diversified power of explantation of interests in relation to various problems. Therefore, holistic approach to the analysis of international relations widens the horizon of research and allows scholars to observe the complexity of perception of an interest in international relations, facilitating the choice of selected interpretations to the specificity of a particular problem (Sadłocha, 207-208).

\section{Works Cited}

Arbatov, A. Pochemu my ne ponimaem drug druga?". "Voenno-promyshlenny Kurier", no. 28(344), 2010.

Areshev, A. DOVSE. Ustarevshii Dogovor i Novye Realii. "Mezhdunarodnaia Zhizn", no. 12, 2007.

Baker, P. Pressure Rising as Obama Works to Rein In Russia. "The New York Times", 2.03.2014. 
Beom, S.S. Russia's Perspectives on International Politics: A Comparison of Liberalist, Realist and Geopolitical Paradigms. "Acta Slavica Iaponica”, no. (26), 2007.

Bogaturov, A. Kontrrevolutsiia tsennostei i mezhdunarodnaia bezopasnost. "Mezhdunarodnyie Protsessy", no. 8(324), 2010.

Bordachev, T. The limits of rational choice Russia in Global Affairs, 4 October 2008.

Burchill, S. The National Interest in International Relations Theory. London, 2005.

Carr, E.H., The Twenty Years' Crisis, 1919-1939. New York: Perennial, 2001.

Chazbijewicz S. Adwet czyli powrót. Walka polityczna Tatarów krymskich o zachowanie tożsamości narodowej i niepodległość państwa po II wojnie Światowej. Olsztyn, 2001.

Clunan, A. The Social Construction of Russia's Resurgence: Aspirations, Identity, and Security Interests. Baltimore MD: The Johns Hopkins University Press, 2009.

Cox, R. Social Forces, States, and World Orders: Beyond International Relations Theory. "Millennium: Journal of International Studies", no. 10, 1981.

Donnelly, J. Realism and International Relations. Cambridge: Cambridge University Press, 2000.

Finnemore, M. National Interests in International Society. New York, 1996.

Gilpin, R. War and Change in World Politics. New York: Cambridge University Press, 1981.

Gostkiewicz, M. Dwa obozy, które mówia różnymi językami. Jak Rosja i Zachód bawia się w propagandowy głuchy telefon. „Gazeta Wyborcza”, 28 March 2014.

Hall, R.B. Moral Authority as a Power Resource. "International Organization", no. 51(4), 1997.

Hamilton, College Levitt Poll. The Russian Elite 2016. Web. https://www.hamilton. edu/documents/russian\%20elite\%202016\%20final\%20ppt.pdf.

Hopf, T. Crimea is ours: A discursive history. "International Relations”, no. 30(2), 2016.

Hopf, T. Social Construction of International Politics: Identities \& Foreign Policies, Moscow, 1955 and 1999. London: Cornell University Press, 2002.

Jusufaj, E. The Kosovo Precedent in the Secession and Recognition of Crimea. "ILIRIA International Review", 01, 2015.

Kapuśniak, T. Ukraina jako obszar wpływów międzynarodowych po zimnej wojnie, Warsaw, 2008.

Karaganov, S. Lucky Russia. Russia in global affairs. 23 March 2011. Web. http://eng. globalaffairs.ru/pubcol/Lucky-Russia-15154.

Kelly, L., Carbonnel Alissa de. Russian markets plunge as Putin tightens Crimea grip. Web. http://www.reuters.com/article/2014/03/03/us-ukraine-crisis -idUSBREA1Q1E82014030.

Keohane, R.O. Joseph S. Nye, Power and Interdependence. New York, 2001

Kropatcheva, E. Russian Foreign Policy in the Realm of European Security through the Lens of Neoclassical Realism. "Journal of Eurasian Studies", no. 3, 2012. 
Levada Center Poll. Russia's role in the world. Web. 25 March 2015, https://www. levada.ru/en/2015/03/25/russia-s-role-in-the-world.

Levada Center Poll. Sankcii: ocenki i ożydanija. Web. 28 August 2014, http: levada. ru/2014/08/28/sanktsii-otsenki-i-ozhidaniya/.

Lobell, S.E., Ripsman, N.M, Taliaferro, J.W. (eds.). Neoclassical realism, the State, and foreign policy. Cambridge: Cambridge University Press, 2009.

Makarychev, A. Russia, Ukraine and the Eastern Partnership: From Common Neighborhood to Spheres of Influence? "Insight Turkey", no. 16(3), 2014. Web. http://file.insightturkey.com/Files/Pdf/russia-ukraine.pdf.

Moravscik, A. Taking Preferences Seriously: A Liberal Theory of International Politics. "International Organization", vol. 51, no. 4, 1997.

Morgenthau, H.J. Politics Among Nations: The Struggle for Power and Peace. New York: Knopf, 1985.

Murray, R. The Return of the Problem-Solvers. Web. http: e-ir.info/2014/03/19/ the-return-of-the-problem-solvers/.

Primakov, Y. Rossiya ishchet novoe mesto v mire. "Izvestiya”, 6 March 1996.

Putin, V. Address by President of the Russian Federation. 18.03.2014. Web. http:// en.kremlin.ru/events/president/news/20603.

Putin, V. Putin deplores collapse of USSR. “BBC News”. Web. 25. April 2005, http:// news.bbc.co.uk/2/hi/4480745.stm.

Putin, V. Reception to Mark 1000 Years since the Death of St. Vladimir, Equal-to-theApostles. Web. 28 July 2015, http://en.kremlin.ru/events/president/news/50068.

Putin, V. Vladimir Putin has been Sworn in as President of Russia. Web. 7 May 2018, http://en.kremlin.ru/events/president/news/57416.

Ruggie, J.G. Constructing the World Polity: Essays on International Institutionalization. London, 1998.

Russian National Security Strategy. Web. December 2015, http:/www.ieee.es/Galerias/ fichero/OtrasPublicaciones/Internacional/2016/Russian-National-SecurityStrategy-31Dec2015.pdf.

Sadłocha, J. Krytyczna analiza kategorii interesu w teorii stosunków międzynarodowych. Wrocław, 2015.

Schweller, R.L., Deadly Imbalances: Tripolarity and Hitler's Strategy of World Conquest. New York, 1998.

Shea, A. Ukraine: Putin's postmodern moment and the politics of truth. Web. $11 \mathrm{March}$ 2014, http://conflictandsecurity.com/blog/ukraine-putins-postmodern-moment -and-the-politics-of-truth.

Singer, J.D., The Level-of-Analysis Problem in International Relations, [in:] K. Knorr and S. Verba (eds.)., The International System: Theoretical Essays. New York, 1961. Slobodchikoff, M.O., Douglas Davis, G. Roots of Russian Soft Power: Rethinking Russian National Identity. "Comparative Politics Russia”, no. 2, 2017. 
Strategiya natsional'noy bezopasnosti Rossiyskoy Federatsii do 2020 goda. Web. 12 May 2009, http://www.kremlin.ru/supplement/424.

Tsygankov, A. Russia's Foreign Policy: Change and Continuity in National Identity. New York: Rowman \& Littlefield, 2010.

Tsygankov, A. Russia's Power and Alliances in the 21 $1^{\text {st }}$ century. "Politics", no. 30(4), 2010.

Vasquez, J. The Power of Power Politics: From Classical Realism to Neotraditionalism. Cambridge: Cambridge University Press, 1998.

Waltz, K. Struktura teorii stosunków międzynarodowych. Warsaw: Scholar, 2010.

Weldes, J. Constructing National Interests: the United States and the Cuban missile crisis. Minnesota: University of Minnesota Press, 1999.

Wendt, A. Anarchy is what States Make of it: The Social Construction of Power Politics. "International Organization", vol. 46, no. 2, 1992.

Wendt, A. Social Theory of International Politics. Cambridge: Cambridge University Press, 1999.

Wielomski, A. Putinowska inna rzeczywistość. Web. http://www.konserwatyzm.pl/ artykul/11851/putinowska-inna-rzeczywistosc.

Wierzbowska-Miazga, A. Konsekwencje aneksji Krymu. Ośrodek Studiów Wschodnich, Web. 19 March 2014, http://www.osw.waw.pl/pl/publikacje/analizy/ 2014-03-19/konsekwencje-aneksji-krymu.

Williams, M. The Realist Tradition and Limits of International Relations. Cambridge: Cambridge University Press, 2005.

Wohlforth, W.C., The Elusive Balance: Power and Perceptions During the Cold War. Ithaca, 1993.

Jarosław Sadłocha - a PhD in social sciences, graduate of the University of Wroclaw. Author of the publication Critical Analysis of the Category of Interest in the Theory of International Relations and co-author of The Nobel Prize as a Symbol of Global Norms and Social Ideas. Scientific interests: theory of international relations, national security, category of interest. 